\title{
Electron beam treatment of simulated marine diesel exhaust gases
}

Janusz Licki, Andrzej Pawelec, Zbigniew Zimek, Sylwia Witman-Zając

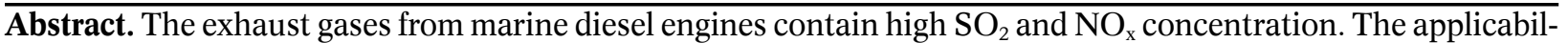
ity of the electron beam flue gas treatment technology for purification of marine diesel exhaust gases containing high $\mathrm{SO}_{2}$ and $\mathrm{NO}_{\mathrm{x}}$ concentration gases was the main goal of this paper. The study was performed in the laboratory plant with $\mathrm{NO}_{\mathrm{x}}$ concentration up to $1700 \mathrm{ppmv}$ and $\mathrm{SO}_{2}$ concentration up to 1000 ppmv. Such high $\mathrm{NO}_{\mathrm{x}}$ and $\mathrm{SO}_{2}$ concentrations were observed in the exhaust gases from marine high-power diesel engines fuelled with different heavy fuel oils. In the first part of study the simulated exhaust gases were irradiated by the electron beam from accelerator. The simultaneous removal of $\mathrm{SO}_{2}$ and $\mathrm{NO}_{\mathrm{x}}$ were obtained and their removal efficiencies strongly depend on irradiation dose and inlet $\mathrm{NO}_{\mathrm{x}}$ concentration. For $\mathrm{NO}_{\mathrm{x}}$ concentrations above 800 ppmv low removal efficiencies were obtained even if applied high doses. In the second part of study the irradiated gases were directed to the seawater scrubber for further purification. The scrubbing process enhances removal efficiencies of both pollutants. The $\mathrm{SO}_{2}$ removal efficiencies above $98.5 \%$ were obtained with irradiation dose greater than $5.3 \mathrm{kGy}$. For inlet $\mathrm{NO}_{\mathrm{x}}$ concentrations of $1700 \mathrm{ppmv}$ the $\mathrm{NO}_{\mathrm{x}}$ removal efficiency about 51\% was obtained with dose greater than $8.8 \mathrm{kGy}$. Methods for further increase of $\mathrm{NO}_{\mathrm{x}}$ removal efficiency are presented in the paper.
\end{abstract}

Key words: electron accelerator $\bullet$ electron beam treatment $\bullet$ free radicals $\bullet$ marine diesel exhaust gases $\bullet \mathrm{NO}_{\mathrm{x}}$ removal • seawater scrubber

\section{J. Licki ${ }^{\bowtie}$}

National Centre for Nuclear Research (NCBJ),

7 Andrzeja Soltana Str., 05-400 Otwock/Swierk,

Poland, Tel.: +48 22273 1144, Fax: +4822 273 1554,

E-mail: janusz.licki@ncbj.gov.pl

A. Pawelec, Z. Zimek, S. Witman-Zajac Institute of Nuclear Chemistry and Technology,

16 Dorodna Str., 03-195 Warsaw, Poland

Received: 24 September 2014

Accepted: 20 May 2015

\section{Introduction}

Around $85 \%$ of worldwide trading goods are moved using maritime routes. High-power diesel engines are mainly applied in the marine transport sector as main engines for ships propulsion at sea and as auxiliary engines at a berth. For economic reasons ships generally use low quality fuel oil with high sulfur content. During combustion the fuel sulfur is oxidized mainly to $\mathrm{SO}_{2} . \mathrm{NO}_{\mathrm{x}}$ emissions from shipping are relatively high because most marine engines operate with high compression. A typical composition of exhaust gas from large two-stroke diesel engine fuelled with heavy fuel oil (HFO) is presented in Fig. 1 [1].

Emissions from shipping contribute significantly to the concentrations of harmful air pollution in Europe [2]. While pollutant emissions from land-based sources are gradually decreasing, those from shipping show a continuous increase (Figs. 2 and 3) [3]. Under current legislation, it is expected that shipping emission of the $\mathrm{SO}_{2}$ and $\mathrm{NO}_{\mathrm{x}}$ will increase by $40-50 \%$ up to 2020 , as compared to 2000 . In both cases, by 2020 the emissions from international shipping around Europe are expected to equal or even surpass the total from all land-based sources in the 27 EU member states combined. The both gases $\left(\mathrm{NO}_{\mathrm{x}}\right.$ and $\left.\mathrm{SO}_{2}\right)$ affect adversely on human health and ecosystem $[4,5]$.

In order to reduce the environmental footprint of ships, the International Maritime Organization 


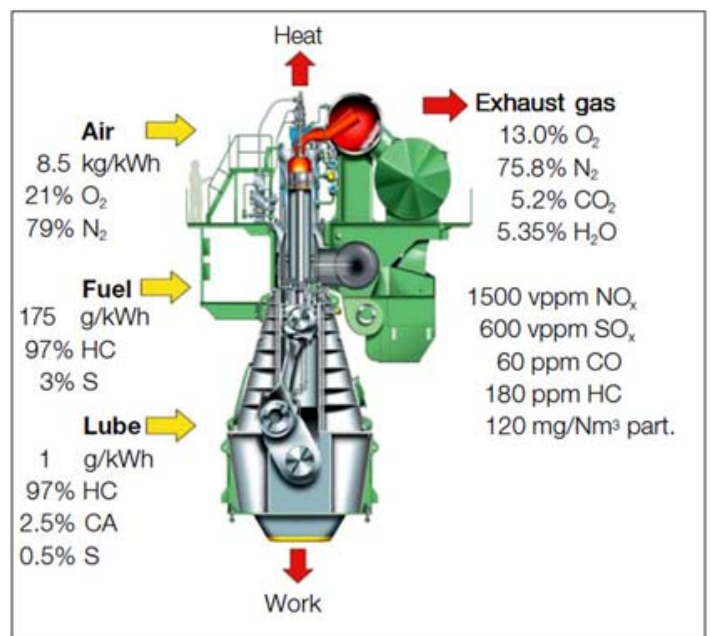

Fig. 1. Flow process and typical exhaust gas composition from two-stroke diesel engine manufactured by MAN B\&W Diesel [1].

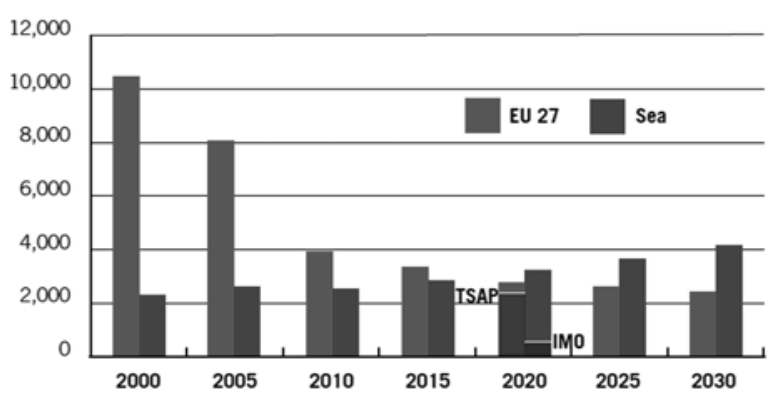

Fig. 2. Emissions of $\mathrm{SO}_{2}$ in Europe in the period 2000-2030 (in ktonnes) [3]. EU27 - emissions from land-based sources in all 27 EU countries (including domestic shipping) combined. Sea - emissions from international shipping in European sea areas. TSAP - target in line with the EU Thematic Strategy on Air Pollution from September 2005. IMO - expected outcome from implementing the preliminary IMO-agreement from April 2008.

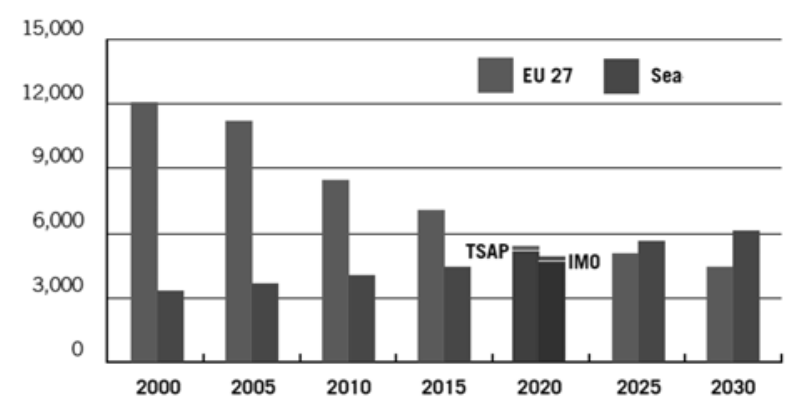

Fig. 3. Emissions of $\mathrm{NO}_{x}$ in Europe in the period 2000-2030 (in ktonnes) [3]. Legend as in Fig. 2.

(IMO) issued the legislation of MARPOL Annex VI guidelines for the Global (all European sea areas) and ECA (emission control area) areas in sulfur content in fuel oil (Fig. 4) and $\mathrm{NO}_{\mathrm{x}}$ emissions based on ship engine operating speed (Fig. 5).

Trying to meet these requirements, ship owners have the alternative, either to operate ships with costly low-sulfur fuels, or to keep HFO burning but adopting proper retrofitting devices.

Several commercial technologies have been implemented on board to reduce the level of $\mathrm{SO}_{\mathrm{x}}$ and $\mathrm{NO}_{\mathrm{x}}$

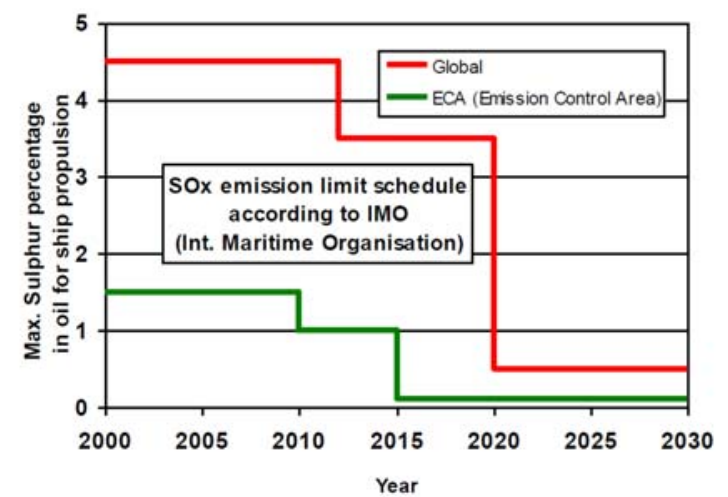

Fig. 4. Maximum allowable sulfur content in fuel oil, according to IMO requirements which are applied to all ships entering a global (all European sea areas) or ECA areas.

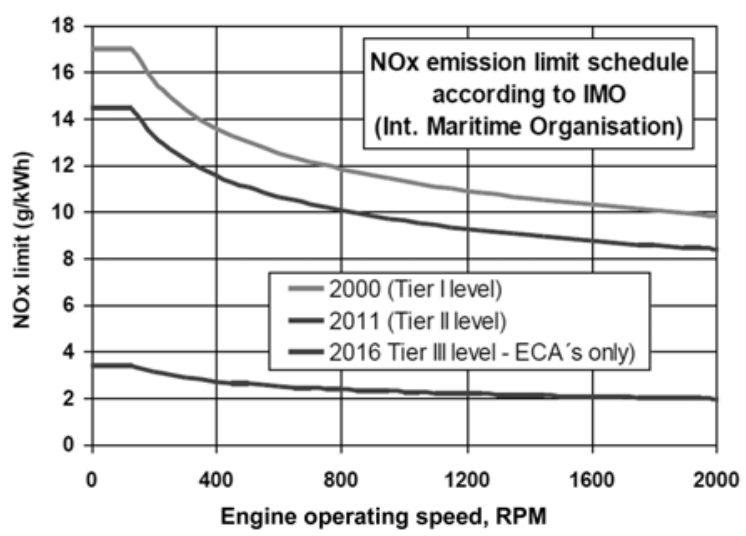

Fig. 5. Maximum allovable fuel specific $\mathrm{NO}_{\mathrm{x}}$ emission rate, according to IMO, MARPOL Annex VI. Tier I and Tier II limits are global, while Tier III standards apply only in $\mathrm{NO}_{\mathrm{x}}$ emission control areas.

from marine diesel engines [6]. Though those technologies can remove $99 \%$ of $\mathrm{SO}_{2}$ and $90 \%$ of $\mathrm{NO}_{\mathrm{x}}$, they posses a number of important drawbacks; two separate technologies for removal of $\mathrm{NO}_{\mathrm{x}}$ and $\mathrm{SO}_{\mathrm{x}}$, require high installation cost as well as a lot of space on the ship and requires large storage of ammonia for the removal of $\mathrm{NO}_{\mathrm{x}}[6]$. The applicability of electron beam flue gas treatment technology (in short, e-beam technology) for purification of marine diesel exhaust gas is the main task of this paper. This technology was originally developed for coal-fired power plants. The simultaneous removal of $\mathrm{SO}_{2}$ and $\mathrm{NO}_{\mathrm{x}}$ with the generation of usable byproducts are its main advantages [7]. The e-beam technology has been already implemented on an industrial scale at three coal-fired power plants: Chengdu and Hangzhou in China [8] and Szczecin "Pomorzany" in Poland [9] (Table 1).

In the e-beam technology, electrons are accelerated by a high voltage in a vacuum region before being injected through thin foil windows to the flue gases at the atmospheric-pressure processing chamber (plasma reactor). The energetic electrons collide with exhaust gas molecules and produce reactive free radicals, atoms, ions and secondary electrons that decompose the pollutants molecules in the irradiated flue gases. The present study was performed with high $\mathrm{NO}_{\mathrm{x}}$ concentration up to 1700 ppmv. Such high $\mathrm{NO}_{\mathrm{x}}$ concentrations were observed in the exhaust gases from marine high- 
Table 1. Main parameters of three industrial e-beam plants

\begin{tabular}{lcccc}
\hline \multicolumn{1}{c}{ Parameters } & Unit & $\begin{array}{c}\text { Chengdu TPP } \\
\text { China }\end{array}$ & $\begin{array}{c}\text { Hangzhou TPP } \\
\text { China }\end{array}$ & $\begin{array}{c}\text { Pomorzany EPS } \\
\text { Poland }\end{array}$ \\
\hline Nominal flue gas flow rate & $\mathrm{Nm}^{3} / \mathrm{h}$ & 300000 & 305400 & 270000 \\
Inlet flue gas temperature & ${ }^{\circ} \mathrm{C}$ & 150 & 145 & 140 \\
Inlet $\mathrm{SO}_{2}$ concentration & $\mathrm{ppmv}$ & 1800 & 970 & 700 \\
Inlet $\mathrm{NO}_{\mathrm{x}}$ concentration & $\mathrm{ppmv}$ & 400 & 200 & 295 \\
$\mathrm{SO}_{2}$ removal efficiency & $\%$ & 80 & 85 & 95 \\
$\mathrm{NO}_{\mathrm{x}}$ removal efficiency & $\%$ & 18 & 55 & 70 \\
Electron beam parameters & $\mathrm{keV}$ & 800 & 800 & 700 \\
& $\mathrm{~mA}$ & $2 \times 400$ & $2 \times 400$ & $4 \times 375$ \\
\hline
\end{tabular}

-power diesel engines fuelled with different heavy fuel oils [10-12].

\section{Experimental}

\section{Test facility}

The study was performed in the laboratory plant at the Institute of Nuclear Chemistry and Technology (INCT) in Warsaw [7], which was additionally equipped with the dosing systems of gaseous $\mathrm{SO}_{2}$ and NO from gas cylinders and the seawater scrubber. Figure 6 presents the flow diagram of test facility. The exhaust gas with high $\mathrm{NO}_{\mathrm{x}}$ concentration was simulated by the gas mixture containing exhaust gas from burning light fuel oil to which gaseous $\mathrm{SO}_{2}$ and NO from gas cylinders were dosing. Such gas mixture was irradiated in the process vessel (point 8 in Fig. 6) under which the scanner of electron accelerator ILU-6M $(800 \mathrm{keV}$, max. beam power up to $20 \mathrm{~kW}$ ) was installed. Two independent extractive monitoring systems were applied for continuous measurement of $\mathrm{SO}_{2}$ and $\mathrm{NO}_{\mathrm{x}}$ concentration in the simulated gas at two crucial points of the plant: at the process inlet (before irradiation, point 6 in Fig. 6) by first system labeled System 1 and at the process outlet (point 12 in Fig. 6) by second system labeled System 2 . The flow rate of the model gas mixture was $5 \mathrm{~m}^{3} / \mathrm{h}$. The residence time of gas mixture in the process vessel was equal to $18 \mathrm{~s}$. The natural gas humidity was 8.48 vol.\% and was not changed during the all tests.

\section{Results and discussion}

The parametric studies were carried out in two steps. In the first step simulated gas mixture was irradiated only by electron beam. In the second step simulated gas mixture undergo the hybrid process of electron beam irradiation plus seawater scrubbing.

\section{First step of parametric studies}

The influence of gas absorbed energy dose (in short, dose) and inlet $\mathrm{NO}_{\mathrm{x}}$ concentration $\left(\mathrm{NO}_{\mathrm{x}}^{0}\right)$ on $\mathrm{NO}_{\mathrm{x}}$ removal efficiency is presented in Fig. 7.

The absorbed dose is a primary factor influencing $\mathrm{NO}_{\mathrm{x}}$ removal. The process starts at zero efficiency for zero dose and indicates saturation at high dose. Higher $\mathrm{NO}_{\mathrm{x}}$ removal was achieved with higher dose and with lower $\mathrm{NO}_{\mathrm{x}}^{0}$ concentration. The active species (free radicals $\mathrm{OH}$ and $\mathrm{HO}_{2}$, atoms $\mathrm{O}, \mathrm{N}$ and $\mathrm{H}$, ions and secondary electrons) formed in plasma reactor by electron beam irradiation oxidize $\mathrm{SO}_{2}$ and $\mathrm{NO}$ to $\mathrm{SO}_{3}$ and $\mathrm{NO}_{2}$ which in reaction with water vapor (present in exhaust gas) form $\mathrm{H}_{2} \mathrm{SO}_{4}$ and $\mathrm{HNO}_{3}$, respectively. $\mathrm{NO}_{\mathrm{x}}$ removal is strongly affected by inlet

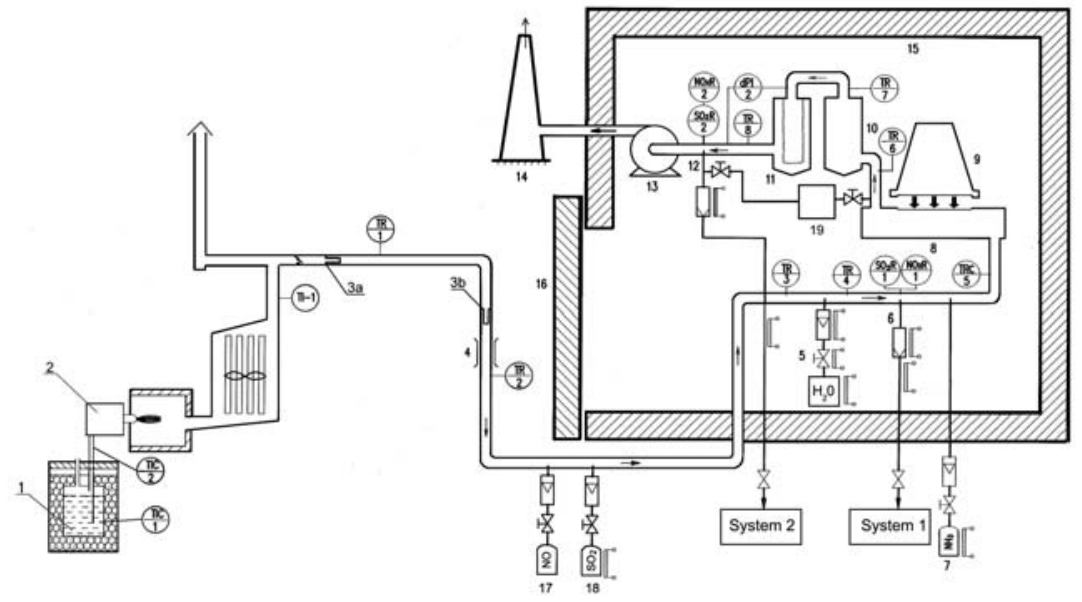

Fig. 6. Flow diagram of the test facility. 1 - termostated fuel oil; 2 - oil burner; $3 a-$ soot filter; $3 b$ - particulate filter; 4 - orifice; 5 - dosage of water vapor; 6 - gas sampling point - process inlet; 7 - ammonia injection; 8 - plasma reactor; 9 - electron beam accelerator; 10 - retention chamber; 11 - bag filter; 12 - gas sampling point-process outlet; 13 - induced-draught fan; 14 - stack; 15 - concrete shielding wall; 16 - concrete shielding door; 17 - NO dosage setup; $18-\mathrm{SO}_{2}$ dosage setup; 19 - seawater scrubber. 


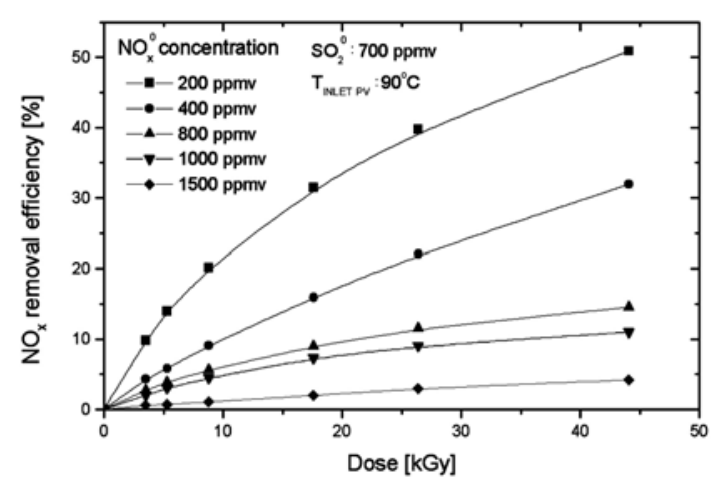

Fig. 7. Effect of absorbed dose on $\mathrm{NO}_{\mathrm{x}}$ removal efficiency.

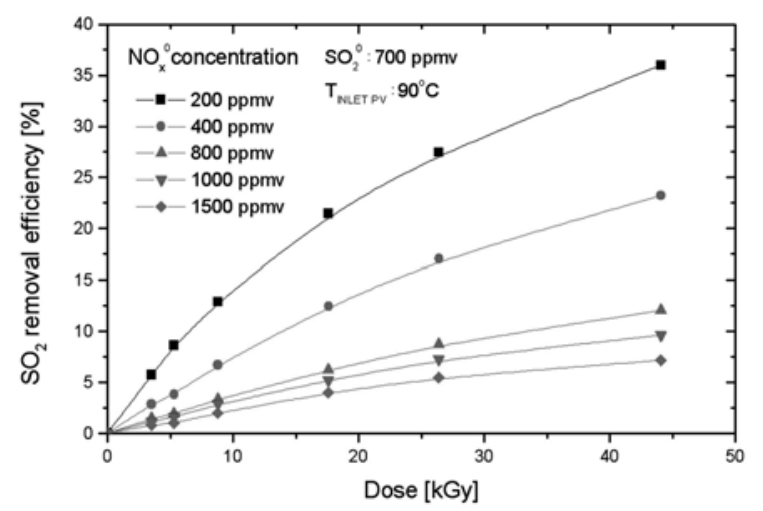

Fig. 8. Effect of absorbed dose on $\mathrm{SO}_{2}$ removal efficiency.

$\mathrm{NO}_{\mathrm{x}}$ concentration. Lower $\mathrm{NO}_{\mathrm{x}}$ removal efficiencies were obtained with increasing $\mathrm{NO}_{\mathrm{x}}^{0}$ concentration even if applied high irradiation doses.

Figure 8 presents the influence of dose and inlet $\mathrm{NO}_{\mathrm{x}}$ concentration on $\mathrm{SO}_{2}$ removal efficiency.

Table 2. $\mathrm{SO}_{2}$ and $\mathrm{NO}_{x}$ removal efficiencies from gas mixtures irradiated in the process vessel at the following conditions: $\mathrm{SO}_{2}^{0}-700$ ppmv, gas temperature $-90^{\circ} \mathrm{C}$ and dose $-17.6 \mathrm{kGy}$

\begin{tabular}{ccc}
\hline \multirow{2}{*}{$\begin{array}{c}\text { Inlet } \mathrm{NO}_{\mathrm{x}} \\
\text { [ppmv] }\end{array}$} & \multicolumn{2}{c}{ Removal efficiencies [\%] } \\
\cline { 2 - 3 } & $\mathrm{NO}_{\mathrm{x}}$ & $\mathrm{SO}_{2}$ \\
\hline 200 & 31.41 & 21.43 \\
400 & 15.92 & 12.43 \\
800 & 9.00 & 6.20 \\
1000 & 7.32 & 5.18 \\
1500 & 1.97 & 3.97 \\
\hline
\end{tabular}

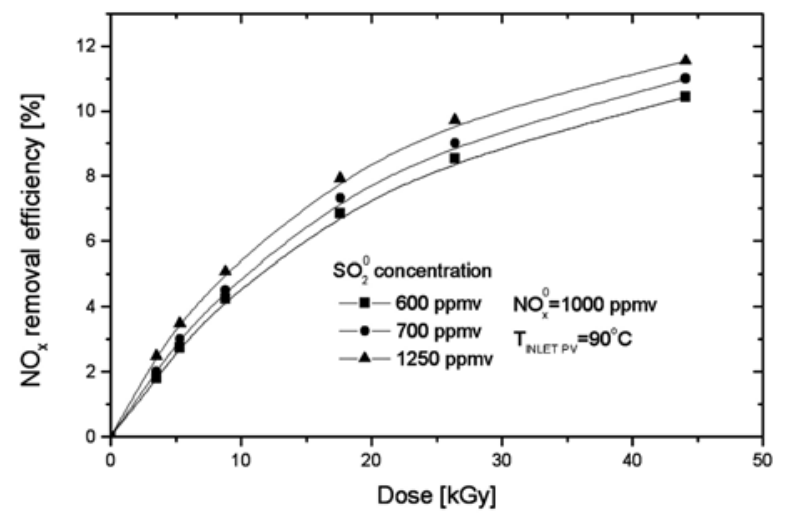

Fig. 9. Effect of inlet $\mathrm{SO}_{2}$ concentration on $\mathrm{NO}_{\mathrm{x}}$ removal efficiency.

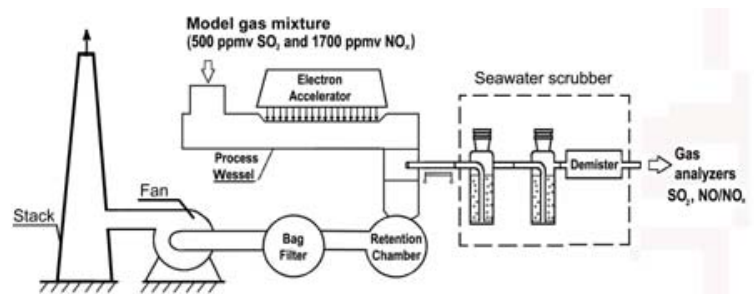

Fig. 10. The schematic diagram of the test facility during the second step of the study.

Electron beam treatment of these gas mixtures with $\mathrm{NO}_{\mathrm{x}}$ concentrations above 800 ppmv ensures low $\mathrm{NO}_{\mathrm{x}}$ and $\mathrm{SO}_{2}$ removal efficiencies. Table 2 presents the summary of the removal efficiencies of both pollutants for different inlet $\mathrm{NO}_{\mathrm{x}}$ concentrations.

The high inlet $\mathrm{SO}_{2}$ concentration $\left(\mathrm{SO}_{2}^{0}\right)$ in the exhaust gas enhances $\mathrm{NO}_{\mathrm{x}}$ removal (Fig. 9). During e-beam irradiation $\mathrm{OH}$ radicals are produced that play the major role in simultaneous oxidation of $\mathrm{NO}$ and $\mathrm{SO}_{2}$ to their respective acids. In the $\mathrm{SO}_{2}$ oxidation are formed of strongly oxidizing radicals $\mathrm{HO}_{2}$ which effectively oxidized NO with regeneration the previously depleted $\mathrm{OH}$ radicals. This process is explained by the following radiation-induced reactions cycle:

$$
\begin{gathered}
\mathrm{SO}_{2}+{ }^{\circ} \mathrm{OH}+\mathrm{M} \rightarrow \mathrm{HSO}_{3}+\mathrm{M} \\
\mathrm{HSO}_{3}+\mathrm{O}_{2} \rightarrow \mathrm{SO}_{3}+\mathrm{HO}_{2}^{\circ} \\
\mathrm{NO}+\mathrm{HO}_{2}^{\circ} \rightarrow \mathrm{NO}_{2}+{ }^{\circ} \mathrm{OH} \\
\mathrm{NO}_{2}+{ }^{\circ} \mathrm{OH}+\mathrm{M} \rightarrow \mathrm{HNO}_{3}+\mathrm{M}
\end{gathered}
$$

\section{Second step of parametric study}

In this step the combined process of e-beam irradiation plus seawater scrubbing was tested. E-beam irradiation of exhaust gas converts insoluble NO (about $95 \%$ of $\mathrm{NO}_{\mathrm{x}}$ ) to fairly soluble $\mathrm{NO}_{2}$ which may be easily removed with the wet scrubber. Seawater is around each ship. It is expected that such solution ensures higher removal efficiency of $\mathrm{SO}_{2}$ and $\mathrm{NO}_{\mathrm{x}}$. Figure 10 presents the schematic diagram of the test facility during the second step of study.

One part of irradiated model gas mixture, leaving process vessel (PV), was directed to the seawater scrubber for further purification. The rest of irradiated model gas mixture passed through the retention chamber, the bag filter and was exhausted through the stack. Figure 11 presents the general view of the test facility.

Figure 12 presents scheme of the seawater arrangement selected for the test facility.

The sample gas passed through two bubbling washers (point 2 in Fig. 12) filled with seawater. Each bottle has a fine fritted dip disc which disperses gas into the millions of small droplets, multiplying the surface area for gas-liquid contacts to ensure high scrubbing efficiency and thereby encouraging transfer species from gas to water. The gas leaving these devices contains droplets of seawater. The demister was installed to precipitate these droplets. Gas leaving the demister was sent to the set of gas analyzers from System 2 to determine the $\mathrm{SO}_{2}$ and $\mathrm{NO} / \mathrm{NO}_{\mathrm{x}}$ concentrations in the such treated gas. Additionally, five manually operated shut off valves $\left(\mathrm{V}_{1}\right.$, 


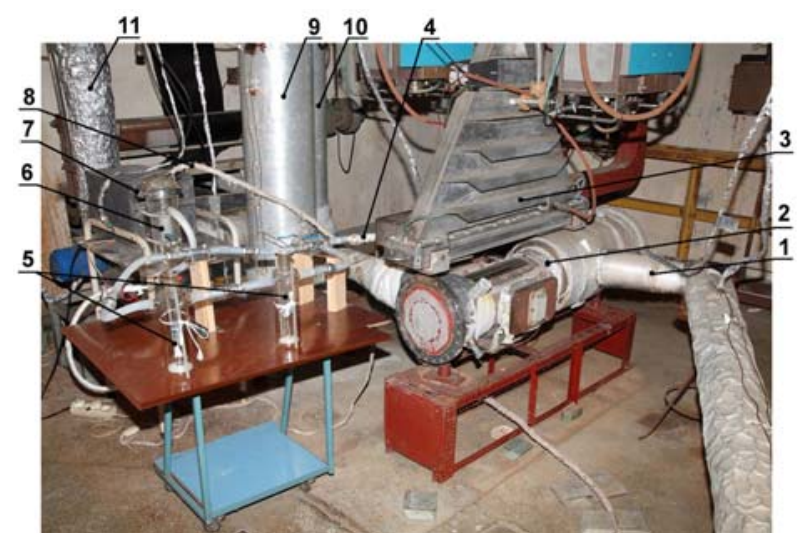

Fig. 11. The general view of the test facility during the second part of the study. 1 - inlet to process vessel; 2 - process vessel with secondary titanium window; 3 - scanner of ILU-6M electron accelerator; 4 - heated sample probe for the seawater scrubber; 5 - two bubbling washers filled with seawater; 6 - demister; 7 - heated sample gas filters; 8 - heated sampling line for set of gas analyzers; 9 - retention chamber; 10 - bag filter; 11 - stack.

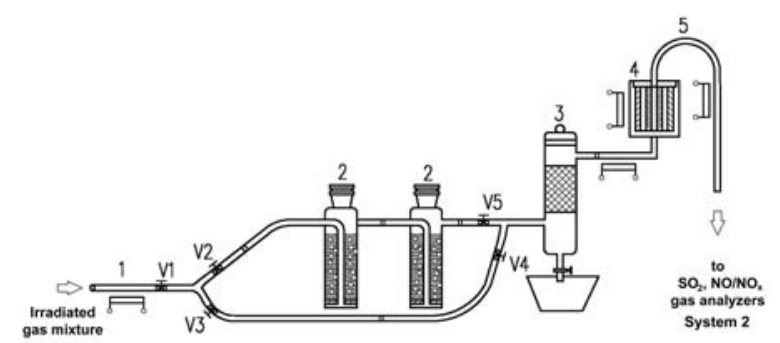

Fig. 12. Scheme of the seawater scrubber arrangement. 1- heated sample probe; 2 - bubbling washer filled with seawater; 3 - demister; 4 - heated ceramic filters; 5 heated sampling line; V1, V2, V3, V4, V5 - shut off valve manually operated.

$\mathrm{V}_{2}, \mathrm{~V}_{3}, \mathrm{~V}_{4}, \mathrm{~V}_{5}$ in Fig. 12) were installed to select the way of irradiated gas mixture. When valves $V_{1}, V_{2}$, and $V_{5}$ were opened and valves $V_{3}$ and $V_{4}$ were shut off, it was possible to study the combined process (e-beam process plus seawater scrubber). When valves $V_{1}, V_{3}$ and $V_{4}$ were opened and valves $V_{2}$ and $V_{5}$ were shut off it was possible to determine $\mathrm{SO}_{2}$ and $\mathrm{NO}_{x}$ removal efficiency only by the e-beam process. The seawater was prepared by addition of suitable amount of pure sodium chloride $(\mathrm{NaCl})$ to the distilled water. Typical seawater contains $3.5 \mathrm{wt} \%$ of $\mathrm{NaCl}$.

Figure 13 presents $\mathrm{NO}_{\mathrm{x}}$ removal efficiencies obtained in two runs with the purification of model gas mixture containing 400 ppmv of $\mathrm{NO}_{\mathrm{x}}$ and $700 \mathrm{ppmv}$ of $\mathrm{SO}_{2}$ using electron beam irradiation (first run) and combined process (second run). Higher $\mathrm{NO}_{\mathrm{x}}$ removal efficiency was obtained in the second run. The scrubbing process enhances removal efficiencies of $\mathrm{SO}_{2}$ and $\mathrm{NO}_{\mathrm{x}}$. The $\mathrm{SO}_{2}$ removal efficiencies greater than $98.5 \%$ were obtained in the combined process with irradiation dose greater than $5.3 \mathrm{kGy}$. During the scrubbing process the $\mathrm{pH}$ of seawater in the bubbling washers was decreased from initial values about 6.0 to 3.1 in the first bubbler and 4.1 in the second bubbler.

Figure 14 presents the effect of seawater salinity on the $\mathrm{NO}_{\mathrm{x}}$ removal efficiency in the combined process. $\mathrm{NO}_{\mathrm{x}}$ removal efficiency increases with increase

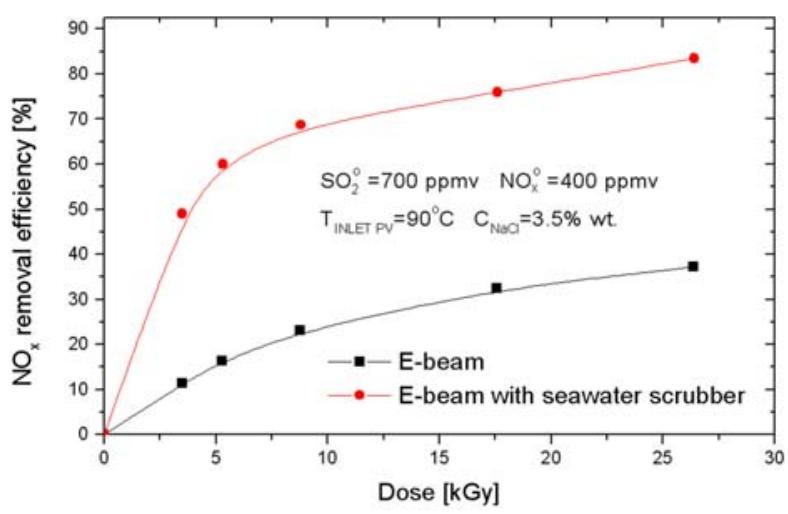

Fig. 13. Comparison of $\mathrm{NO}_{\mathrm{x}}$ removal efficiencies obtained only in e-beam process and in e-beam process combined with seawater scrubber.

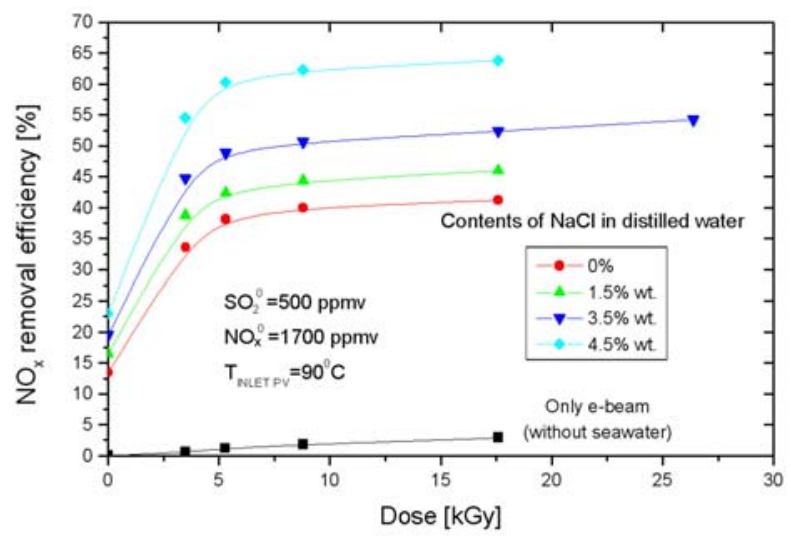

Fig. 14. Effect of seawater salinity on the $\mathrm{NO}_{\mathrm{x}}$ removal efficiency obtained in the e-beam process combined with seawater scrubber.

seawater salinity. The scrubbing process is more effective in the more saline waters.

Table 3 presents the effect of gas temperature at the process vessel inlet on the $\mathrm{SO}_{2}$ and $\mathrm{NO}_{\mathrm{x}}$ removal efficiency in the combined process. $\mathrm{NO}_{\mathrm{x}}$ removal efficiency increases with increase of irradiated gas temperature.

Table 4 presents the summary of the effect of inlet $\mathrm{SO}_{2}$ concentration on $\mathrm{NO}_{\mathrm{x}}$ removal efficiency obtained in the combined process.

High inlet $\mathrm{SO}_{2}$ concentration enhances $\mathrm{NO}_{x} \mathrm{re}-$ moval efficiencies. Such improvement was already observed in the e-beam process.

\section{Conclusions}

Tests with the purification of simulated exhaust gases from marine diesel engines were performed in the INCT laboratory plant. As first, the electron beam flue gas treatment technology was applied. The simultaneous removal of $\mathrm{SO}_{2}$ and $\mathrm{NO}_{\mathrm{x}}$ was obtained. Their removal efficiency strongly depends on irradiation dose, inlet $\mathrm{NO}_{\mathrm{x}}$ concentration, and inlet gas temperature. For $\mathrm{NO}_{\mathrm{x}}$ concentration above 800 ppmv, low $\mathrm{NO}_{\mathrm{x}}$ and $\mathrm{SO}_{2}$ removal efficiencies were obtained even if high irradiation doses were applied. In the second part of study, the irradiated gases (after e-beam process) were directed to the seawater scrubber for 
Table 3. Effect of gas temperature on $\mathrm{NO}_{\mathrm{x}}$ and $\mathrm{SO}_{2}$ removal efficiencies in the combined process. The experimental conditions: $\mathrm{SO}_{2}^{0}=500$ ppmv, $\mathrm{NO}_{\mathrm{x}}^{0}=1700 \mathrm{ppmv}$, dose $=8.8 \mathrm{kGy}, \mathrm{C}_{\mathrm{NaCl}}=3.5 \mathrm{wt} \%$

\begin{tabular}{lcccc}
\hline \multicolumn{1}{c}{ Parameter } & Unit & \multicolumn{2}{c}{ Value } \\
\hline Gas temperature & ${ }^{\circ} \mathrm{C}$ & 70 & 90 & 100 \\
$\mathrm{NO}_{\mathrm{x}}$ removal efficiency & $\%$ & 48.02 & 50.57 & 51.95 \\
$\mathrm{SO}_{2}$ removal efficiency & $\%$ & 98.15 & 97.06 & 96.00 \\
Final pH value of seawater in the bubbler: & & & 3.176 & 3.067 \\
- first & - & 3.220 & 3.748 & 3.706 \\
- second & - & 3.824 & \\
\hline
\end{tabular}

Table 4. Effects of the inlet high $\mathrm{SO}_{2}$ concentration on $\mathrm{NO}_{\mathrm{x}}$ removal efficiency obtained in the combined process. The experimental conditions: $\mathrm{NO}_{\mathrm{x}}^{0}=1700 \mathrm{ppmv}, T_{\mathrm{INLET} \mathrm{PV}}=90^{\circ} \mathrm{C}$, dose $=8.8 \mathrm{kGy}, \mathrm{C}_{\mathrm{NaCl}}=3.5 \mathrm{wt} \%$

\begin{tabular}{|c|c|c|c|c|}
\hline Parameter & Unit & & Value & \\
\hline Inlet $\mathrm{SO}_{2}$ concentration & ppmv & 0 & 500 & 1000 \\
\hline $\mathrm{NO}_{\mathrm{x}}$ removal efficiency & $\%$ & 46.01 & 50.57 & 51.20 \\
\hline \multicolumn{5}{|c|}{ Final seawater $\mathrm{pH}$ in the bubbler: } \\
\hline - first & - & 3.606 & 3.176 & 2.846 \\
\hline - second & - & 3.910 & 3.748 & 3.661 \\
\hline \multicolumn{5}{|c|}{ Change of seawater temperature in the bubbler: } \\
\hline - first & ${ }^{\circ} \mathrm{C}$ & 0.1 & 0.3 & 0.5 \\
\hline - second & ${ }^{\circ} \mathrm{C}$ & 0.2 & 0.3 & 0.6 \\
\hline
\end{tabular}

further purification. High $\mathrm{SO}_{2}$ removal up to $99 \%$ and $\mathrm{NO}_{\mathrm{x}}$ up to $51 \%$ were obtained for exhaust gases with 1700 ppmv of $\mathrm{NO}_{\mathrm{x}}$ concentration. Scrubbing process ensures high removal efficiencies because:

- electron beam process converts insoluble NO (about 95\% of $\mathrm{NO}_{\mathrm{x}}$ ) to fairly soluble and reactive $\mathrm{NO}_{2}$ which may be removed with wet scrubber. The $\mathrm{SO}_{2}$ is also oxidized to $\mathrm{SO}_{3}$. Such formed $\mathrm{NO}_{2}$ and $\mathrm{SO}_{3}$ in reaction with water vapor, presented in exhaust gases, form nitric and sulfuric acids, respectively,

- scrubber consisted of two bubbling washers filled with seawater and demister. Each bubbling washer was equipped with a fine fritted dip disc which disperses gas into the millions of small droplets, multiplying the surface area for gas-liquid contacts to ensure high scrubbing efficiency and thereby encouraging transfer species from gas to water,

- during the scrubbing process the $\mathrm{pH}$ value of seawater drops to about 3.0 which makes very good medium for scrubbing of $\mathrm{NO}_{\mathrm{x}}$.

In the combined process, $\mathrm{SO}_{2}$ and $\mathrm{NO}_{\mathrm{x}}$ removal efficiencies were strongly dependent on the irradiation dose and salinity of seawater. Irradiated gas temperature dependence was moderate. The presence of high $\mathrm{SO}_{2}$ concentration in the exhaust gases enhances $\mathrm{NO}_{\mathrm{x}}$ removal efficiency. Thus such solution is preferable for engines fuelled with high sulfur fuel oil.

The Tier II requires $80 \%$ reduction of $\mathrm{NO}_{\mathrm{x}}$ concentration in the exhaust gases from marine diesel engine. In the performed tests $\mathrm{NO}_{\mathrm{x}}$ removal efficiencies up to $51 \%$ were obtained. Further increase of $\mathrm{NO}_{\mathrm{x}}$ removal may be obtained by addition to the seawater a reducing solution to reduce $\mathrm{NO}_{2}$ to $\mathrm{N}_{2}$ with minimum byproducts. Such tests will be performed at INCT laboratory plant. A remarkable reduction of energy consumption in the e-beam process can be achieved with multistage exhaust gas irradiation. Tests performed in Kawęczyn pilot plant have demonstrated about $10-15 \%$ reduction by double irradiation [13].
Acknowledgments. This work was supported by the Ministry of Science and Higher Education, project W141/7.PR UE/2014 "The industrial and environmental application of electron beams".

\section{References}

1. MAN B\&W Diesel. (2004). Emission control, MAN $B \& W$ Two-stroke Diesel Engines. Copenhagen, Denmark.

2. Kristensen, H. O. (2012). Energy demand and exhaust gas emissions of marine engines. Technical University of Denmark, Project no. 2010-56, Work Package 2. (Report no. 05).

3. Air pollution from ships. (2008). Report prepared by: European Federation for Transport and Environment, Swedish NGO Secretariat on Acid Rain, North Sea Foundation, Bellona Foundation, European Environmental Bureau and Seas at Risk. Visby, Sweden: Snabba Tryck.

4. US EPA. (2011). Risk assessment for toxic air pollutants. A citizen's guide. (EPA 450/3-90-024).

5. US EPA. (2014). Health effects of air pollution. US EPA Region 7 Air Program, 4 April 2014. Available from http://wwa.epa.gov/region07/air/quality/health. htm.

6. Jurgensen, R., Mikaelsen, R., \& Heslop, J. (2011). State of the art and efficiency report. Report D2.1 in the project: Technologies and scenarios for low emissions shipping. Document: RJ-WP2-G2.1-V07-07/2011.

7. Chmielewski, A. G., Ostapczuk, A., \& Licki, J. (2010). Electron beam technology for multipollutant emissions control from heavy fuel oil-fired boiler. J. Air Waste Manage. Assoc., 62, 932-499.

8. Doi, Y., Nakanishi, J., \& Konno, Y. (2000). Operational experience of a commercial scale plant of electron beam purification of flue gas. Radiat. Phys. Chem., 57, 495-499.

9. Chmielewski, A. G., Licki, J., Pawelec, A., Tymiński, B., \& Zimek, Z. (2004). Operational experience of the industrial plant for electron beam flue gas treatment. Radiat. Phys. Chem., 71, 435-440. 
10. Agrawal, H., Malloy, Q. G. I., Welch, W. A., Miller, I. W., \& Cocker, D. R. (2008). In-use gaseous and particulate matter emissions from a modern ocean going container vessel. Atmos. Environ., 42, 5504-5510.

11. Cooper, D. A. (2001). Exhaust emissions from high speed passenger ferries. Atmos. Environ., 35, 3189-4200.
12. Cooper, D. A. (2003). Exhaust emissions from ships at berth. Atmos. Environ., 37, 3817-3830.

13. Chmielewski, A. G., Licki, J., Dobrowolski, A., Tymiński, B., Iller, E., \& Zimek, Z. (1995). Optimization of energy consumption for $\mathrm{NO}_{\mathrm{x}}$ removal in multistage gas irradiation process. Radiat. Phys. Chem., 45, 1077-1079. 